\title{
PROFIL ANATOMI DAUN CABAI MERAH KERITING (Capsicum annuUm L.) AKIBAT PEMBERIAN EKSTRAK AIR BIJI KEMBANG SUNGSANG (Gloriosa superba L.)
}

\author{
ANATOMY PROFILES OF CURLY RED CHILI LEAF (Capsicum annuUm L.) \\ TREATED BY SEED EXTRACT OF KEMBANG SUNGSANG (Gloriosa superbaL.)
}

\author{
Annisa Destiliani ${ }^{1}$, Eti Ernawiati ${ }^{1}$, Yulianty ${ }^{1}$ \\ Jurusan Biologi FMIPA Universitas Lampung \\ E-mail: Queenneesa@yahoo.com \\ Jurusan Biologi FMIPA Universitas Lampung \\ Jl. Soemantri Brojonegoro No.1, Bandar Lampung, Lampung, Indonesia, 35145
}

\begin{abstract}
Abstrak
Penelitian profil anatomi daun cabai merah keriting akibat pemberian ektrak biji Kembang sungsang telah dilakukan dari bulan November 2012 - April 2013 di Laboratorium Botani Jurusan Biologi FMIPA Universitas Lampung. Penelitian disusun dengan Rancangan Acak Kelompok (RAK) dengan 2 faktor perlakuan. Faktor pertama adalah konsentrasi (A) terdiri atas $0,025 \%, 0,05 \%, 0,075 \%, 0,1 \%$ dan $0 \%$ sebagai kontrol. Faktor kedua adalah cara perendaman (B) terdiri perendaman biji cabai dan kecambah cabai dalam ekstrak biji Kembang sungsang. Parameter yang diamati adalah indeks stomata serta ukuran stomata dan sel epidermis. Hasil analisis pada $\alpha=5 \%$ menunjukkan bahwa konsentrasi ekstrak biji Kembang sungsang 0,025\% dan perendaman kecambah dalam ekstrak biji Kembang sungsang menghasilkan profil anatomi daun cabai merah keriting terbaik yaitu indeks stomata $22.450 \%$, dengan kisaran ukuran sel stomata $29,1-30,8 \times 22,1-24,6 \mu \mathrm{m}$ dan kisaran ukuran sel epidermis $76,5-80,0 \times 37,5-39,0 \mu \mathrm{m}$.
\end{abstract}

Kata Kunci: kembang sungsang, cabai merah keriting, anatomi daun

\begin{abstract}
Study on the anatomy profiles of curly red chili leaf treated by seed extracts of kembang sungsang was conducted from November 2012 to April 2013 in the Laboratory of Botany, Department of Biology, Lampung University. Research was compiled by randomized block design (RBD) with 2 factors. The first factor was the concentration of kembang sungsang seed extract (A) consisting of $0.025 \%, 0.05 \%, 0.075 \%, 0.1$ and $0 \%$ as control. The second factor was the immersion in seed extract of Gloriosa superba(B) comprises of soaking seeds and sprouts of red chili. Parameters measured were stomatal index, stomatal size, and epidermal cell size. Results of the analysis varians at $\alpha=5 \%$ showed that soaking of red chily sprouts in the Gloriosa superba extract seed concentration of $0.025 \%$ produce the best anatomical profile of curly red chili leaves with the stomatal index of $22.450 \%$, stomatal size range of 29,1 to $30,8 \times 22,1$ to $24,6 \mu \mathrm{m}$ and epidermal cell size range of 76,5 to $80,0 \times$ 37,5 to $39,0 \mu \mathrm{m}$.
\end{abstract}

Key Word : kembang sungsang, red chili, leaf anatomy

\section{PENDAHULUAN}

Kembang sungsang (Gloriosa superba L.) merupakan salah satu tanaman hias yang seluruh bagian tubuhnya mengandung kolkisin (Acharya et al., 2005). Kolkisin dapat digunakan untuk menginduksi tanaman menjadi poliploid. Sumber kolkisin pada kembang sungsang yang terbaik adalah biji sekitar 1,32 \% (Rajagopal and Kandhasamy, 2009). Tanaman poliploid menunjukkan kualitas dan pertumbuhan yang lebih baik, salah satunya dapat dilihat dari anatomi daun (Thomas, 1993). Karakteristik anatomi daun meliputi ketebalan kutikula, tebal daun, tebal palisade, ukuran stomata dan jumlah daun. In- deks stomata (IS) adalah perbandingan antara jumlah stomata dengan jumlah total epidermis ditambah stomata, dimana tiap satu stoma dihitung sebagai satu sel. Sifat umum tanaman poliploid adalah memiliki ukuran bagian-bagian tanaman lebih besar, meliputi akar, batang, daun, bunga, atau buah. Warna daun lebih tua, tinggi tanaman relatif lebih tinggi, jumlah anakan dan jumlah daun lebih banyak sebagai akibat pemberian kolkisin, resistensi terhadap penyakit lebih baik dan rasa lebih enak (Suryo, 1995). Setiap tanaman mempunyai kisaran konsentrasi dan waktu perlakuan tersendiri untuk menimbulkan poliploid (Hetharie, 2003). 
Penelitian menggunakan ekstrak kolkisin dari umbi dan daun tanaman kembang sungsang terhadap perubahan fenotip tanaman cabai merah keriting telah dilakukan (Ernawiati et al, 2008; Rajagopal and Kandhasamy, 2009), namun kajian penelitian ekstrak kolkisin dari biji kembang sungsang terhadap anatomi daun belum banyak dilakukan. Mengingat hal ini, maka dilakukan penelitian menggunakan ekstrak kolkisin dari biji kembang sungsang untuk meningkatkan kualitas tanaman, khususnya tanaman cabai merah keriting (Capsicum annuum L.).

\section{METODE PENELITIAN}

Penelitian dilaksanakan di Laboratorium Botani Jurusan Biologi FMIPA Universitas Lampung dari bulan November 2012 sampai bulan April 2013. Bahan uji adalah cabai merah keriting yang diperoleh dari toko pertanian yang ada di Bandar lampung dan biji Kembang sungsang diperoleh dari koleksi pribadi Eti Ernawiati. Pewarna safranin digunakan untuk memperjelas preparat stomata yang dibuat.

\section{Cara Kerja}

Penelitian disusun menggunakan Rancangan Acak Kelompok (RAK) dengan 2 faktorial. Faktor pertama adalah konsentrasi (A) terdiri atas $0,025 \%, 0,05 \%, 0,075 \%, 0,1 \%$ dan kontrol $(0 \%)$. Faktor kedua adalah cara perendaman (B) terdiri atas biji cabai direndam ekstrak air biji Kembang sungsang dan kecambah cabai direndam ekstrak air biji Kembang sungsang. Parameter yang diamati adalah indeks stomata, ukuran stomata, dan ukuran sel epidermis. Data diuji homogenitasnya sebelum dianalisis menggunakan analisis ragam. Parameter yang menunjukkan beda nyata diuji lanjut untuk melihat perbedaan antar perlakuan menggunakan uji BNT. Semua analisis yang dilakukan menggunakan $\alpha=5 \%$.

\section{Pembuatan ekstrak air biji kembang sungsang}

Pembuatan ekstrak pekat biji Kembang sungsang dilakukan di Laboratorium Biokimia Jurusan Kimia FMIPA Universitas Lampung dengan menggunakan metode Harborne (Harborne, 1996). Biji Kembang sungsang dibersihkan dan dikeringkan kemudian digiling. Biji yang telah menjadi serbuk $(50 \mathrm{~g})$ dimaserasi. Hasil maserasi dipekatkan dengan suhu $-68^{\circ} \mathrm{C}$ dalam Frize Dryer sehingga dihasilkan ekstrak pekat 0,5 .

\section{Pembuatan larutan untuk perlakuan}

Konsentrasi ekstrak biji kembang sungsang yang digunakan adalah $0 \%, 0,025 \%, 0,05 \%$, $0,075 \%$, dan $0,1 \%$ diperoleh melalui pengenceran.

\section{Pemberian perlakuan pada sampel}

Sebanyak 30 benih cabai direndam selama 48 jam di dalam cawan petri yang berisi ekstrak air Kembang sungsang dengan masing-masing konsentrasi $0 \%, 0,025 \%, 0,05 \%, 0,075 \%$, dan $0,1 \%$.

Sebanyak 30 benih cabai ditumbuhkan dalam cawan petri sampai berkecambah dan tumbuh akar sepanjang 3-5 mm. Benih yang telah berkecambah direndam selama 48 jam di dalam cawan petri yang berisi ekstrak dengan masingmasing konsentrasi $0 \%, 0,025 \%, 0,05 \%$, $0,075 \%$, dan $0,1 \%$.

\section{Penanaman}

Setelah kecambah berumur 21 hari, 15 buah kecambah ditanam dalam pot berisi tanah bercampur kompos. Pengamatan stomata dilakukan setelah tanaman berumur 4 minggu setelah penanaman.

\section{Preparasi anatomi daun}

Daun yang diamati diambil dari daun kesepuluh dari setiap tanaman cabai. Daun dikerik menggunakan silet tajam pada sisi permukaan bawah sampai diperoleh suatu lapisan yang tipis kemudian ditetesi safranin. Ukuran stomata diukur menggunakan micrometer pada perbesaran 1.000x. Pengamatan indeks stomata menggunakan perbesaran $400 x$, indeks stomata (IS) dihitung menggunakan rumus dari Taulu (Royer,2001) yaitu :

$$
\text { IS }=\frac{\text { jumlah stomata }}{\text { jumlah stomata }+ \text { jumlah sel epidermis }} \times 100 \%
$$

\section{HASIL dan PEMBAHASAN}

Pada Tabel 1 dapat dilihat bahwa konsentrasi ekstrak air biji Kembang sungsang 0,1\% menghasilkan indeks stomata (IS) tertinggi dibandingkan dengan konsentrasi yang lainnya. Nilai IS terkecil dijumpai pada konsentrasi $0,025 \%$. Sedangkan konsentrasi 0\%, 0,05\%, dan $0,075 \%$ tidak menunjukkan perbedaan.

Tabel 1. Rerata indeks stomata daun cabai merah keriting dengan konsentrasi ekstrak air biji Kembang sungsang

\begin{tabular}{cc}
\hline Konsentrasi Ekstrak & Rerata Indeks Stomata (\%) \\
\hline $0 \%$ & $24.436^{\mathrm{b}}$ \\
$0,025 \%$ & $22.450^{\mathrm{c}}$ \\
$0,05 \%$ & $23.453^{\mathrm{bc}}$ \\
$0,075 \%$ & $24.720^{\mathrm{b}}$ \\
$0,1 \%$ & $26.753^{\mathrm{a}}$ \\
\hline Keterangan : Nilai yang diikuti dengan huruf yang sama \\
tidak berbeda nyata pada $\alpha=5 \%$.
\end{tabular}


Peningkatan ukuran stomata mengindikasikan penurunan frekuensi stomata (indeks stomata) pada tanaman cabai yang termutasi. Hal ini dapat dimengerti karena ukuran yang besar akan menyebabkan jumlah stomata per satuan luas berkurang (Rauf et al., 2006 dan Zolock, 2003). Sedangkan bentuk (tipe) stomata tidak mengalami perubahan oleh adanya pemberian biomutagen dimana sel penutup dikelilingi tiga buah sel tetangga yang tidak sama besar yang bisa dikenal dengan stomata tipe Anisositik (cruciferous) (Estiti, 1995).

Hasil ini tidak sama dengan yang diperoleh pada penelitian Permadi et al. (1991) yang mendapatkan adanya interaksi antara konsentrasi kolkisin dan lama perendaman pada bawang merah Sumenep. Meskipun demikian, hasil penelitian yang diperoleh memiliki kecenderungan yang homogen, yaitu jumlah stomata sedikit (IS kecil), daun lebih tebal dengan pembesaran pada panjang dan lebar sel penjaga stomata dibandingkan tanaman kontrol (0\%). Hal ini diduga disebabkan beberapa faktor, antara lain tanaman uji dan sumber kolkisin yang digunakan berbeda. Pada penelitian sebelumnya (Permadi et al.,1991), kolkisin yang digunakan adalah kolkisin murni sehingga memiliki daya kerja yang lebih baik, sedangkan dalam penelitian ini adalah ekstrak air biji Kembang sungsang sehingga kandungan senyawa aktif kolkisinnya memiliki daya kerja yang kurang karena masih tercampur dengan senyawa aktif lainnya. Konsentrasi kolkisin murni yang umum digunakan berkisar antara 0,001-1,00 \% dengan waktu kontak antara 24-96 jam (Eigsti dan dustin, 1957; Suryo, 1995).

Tabel 2. Rerata indeks stomata daun cabai merah keriting yang direndam ekstrak biji Kembang sungsang

\begin{tabular}{cc}
\hline Perlakuan perendaman & Rerata Indeks Stomata (\%) \\
\hline Kecambah & $27.446^{\mathrm{a}}$ \\
Biji & $21.279^{\mathrm{b}}$ \\
\hline $\begin{array}{l}\text { Keterangan : Nilai yang diikuti dengan huruf yang sama } \\
\text { tidak berbeda nyata pada } \alpha=5 \% .\end{array}$
\end{tabular}

Pada Tabel 2 diatas dapat dilihat bahwa perendaman kecambah dalam ekstrak air biji Kembang sungsang menghasilkan IS lebih tinggi dibandingkan biji yang direndam ekstrak air biji Kembang sungsang. Hal ini diduga bahwa perendaman kecambah cabai dalam ekstrak air biji Kembang sungsang mampu meningkatkan proses pertumbuhan kecambah. Poehlman dan Sleper (1995) mengatakan bahwa kolkisin lebih efektif pada biji yang sedang berkecambah, tanaman semaian muda, atau bagian meristem tanaman yang sedang berkembang, seperti ujung batang.

Hasil pengamatan pada Tabel 3 menunjukkan pengaruh perlakuan konsentrasi dan cara perendaman ekstrak biji kembang sungsang menghasilkan rerata kisaran ukuran stomata dan ukuran epidermis terbaik pada konsentrasi $0,025 \%$.

Tabel 3. Rerata kisaran ukuran sel stomata daun cabai merah keriting dengan konsentrasi dan cara perendaman ekstrak air biji Kembang sungsang

\begin{tabular}{cccc}
\hline & Perlakuan & Rerata ukuran stomata $(\mu \mathrm{m})$ & Rerata ukuran epidermis $(\mu \mathrm{m})$ \\
\hline \multirow{3}{*}{ Kecambah } & $0 \%$ & $(28,6-29,2) \times(21,7-24,3)$ & $(62,5-65,5) \times(32,0-33,0)$ \\
& $0,03 \%$ & $(29,1-30,8) \times(22,1-24,6)$ & $(76,0-78,5) \times(38,0-41,5)$ \\
& $0,05 \%$ & $(27,5-29,8) \times(22,5-24,2)$ & $(69,0-75,0) \times(41,5-52,0)$ \\
& $0,08 \%$ & $(28,9-29,2) \times(21,7-23,9)$ & $(63,5-71,5) \times(36,0-39,5)$ \\
& $0,10 \%$ & $(24,9-28,5) \times(21,9-23,8)$ & $(68,0-71,5) \times(31,5-36,5)$ \\
\hline \multirow{3}{*}{ Biji } & $0 \%$ & $(25,4-25,7) \times(22,0-22,3)$ & $(66,0-68,5) \times(30,0-33,0)$ \\
& $0,03 \%$ & $(27,8-29,5) \times(21,1-22,8)$ & $(76,5-80,0) \times(37,5-39,0)$ \\
& $0,05 \%$ & $(25,7-28,8) \times(21,2-21,9)$ & $(75,0-77,0) \times(39,0-42,0)$ \\
& $0,08 \%$ & $(26,6-27,7) \times(21,9-23,8)$ & $(68,5-70,5) \times(33,0-35,5)$ \\
& $0,10 \%$ & $(25,5-26,3) \times(20,7-22,2)$ & $(68,0-71,0) \times(29,0-31,0)$ \\
\hline
\end{tabular}

Peningkatan ukuran stomata dan sel epidemis terdapat pada konsentrasi $0,025 \%$ dengan $u$ kuran kisaran berturut-turut $29,1-30,8 \times 22,1$ $24,6 \mu \mathrm{m}$ dengan rerata $30,1 \times 23,3 \mu \mathrm{m}$ dan $76,5-80,0 \times 37,5-39,0 \mu \mathrm{m}$ dengan rerata $78,3 \times$ $38,2 \mu \mathrm{m}$. Hal ini diduga karena adanya kandungan senyawa kolkisin yang menyebabkan poliploid, sehingga ukuran sel stomata dan sel epidermis menjadi lebih besar dan jumlah da- lam satu bidang perbesaran menjadi meningkat. Hal ini sesuai dengan penelitian Suryo (1995), yang menyatakan bahwa tanaman poliploid menyebabkan sel-selnya (tampak jelas pada sel epidermis) lebih besar, inti sel juga membesar dan stomata menjadi besar. Hal ini sejalan juga dengan hasil penelitian Griffiths et al. (1996), pada tanaman tembakau, bahwa semakin tinggi tingkat ploidi semakin besar u- 
kuran sel dan stomatanya. Dalam hal ini terlihat adanya hubungan yang sebanding antara tingkat ploidi dengan ukuran stomata.

\section{SIMPULAN}

Hasil penelitian ini menunjukkan bahwa perendaman benih dan kecambah cabai merah keriting (Capsicum annuum L.) dalam ekstrak biji kembang sungsang mampu meningkatkan ukuran sel stomata dan sel epidermis daun cabai merah keriting. Konsentrasi dan cara perendaman yang memberikan hasil yang optimal yaitu konsentrasi $0,025 \%$ dan perendaman kecambah dengan lama perendaman 48 jam.

\section{DAFTAR PUSTAKA}

Acharya, Deepak, A. Shrivastavaand, dan S. Garima. 2005. Gloriosa superba : Naturally a Handsome Herb. Indigenous Herbal Medicines: Tribal Formulations and Traditional Herbal Practices, Aavishkar Publishers Distributor, Jaipur-India, ISBN 978-81-7910-252-7, 2008, 440.

Eigsti, O.J., and P. Dustin. 1957. Colchicine and Agriculture Medicine, Biology and Chemistry. Lowa State College Press, lowa.

Ernawiati, E., S. Wahyuningsih, dan Yulianty. 2008. Penampilan Fenotifik Tanaman Cabai Merah Hasil Poliploidisasi dengan Ekstrak Umbi Kembang Sungsang (Gloriosa superba L.). Prosiding Seminar Sains dan Teknologi II, ISBN 978-9791165-74-7. Hal. 375.

Estiti, H. B. 1995. Anatomi Tubuhan Berbiji. Bandung : ITB.

Griffiths, A.J.F.,J. H. Miller, P. T. Suzuki, R. C. Lewondr, and W. M. Gelbart. 1996. An Introduction to Genetic Analysis. Edisi ke6, W.H. Freeman and Co. New York.
Harborne, J.B., 1996. Metode Fitokimia: Penuntun Modern Cara Menganalisis Tumbuhan, Penerjemah Padmawinata, K dan I. Soediro, Penerbit ITB, Bandung.

Hetharie, H. 2003. Perbaikan sifat tanaman melalui pemuliaan poliploidi. Makalah Individu Pengantar Falsafah Sains (PPS702) Program Pascasarjana / S3. Institut Pertanian Bogor.

Permadi, A.H, R Cahyani, S. Syarif. 1991. Cara Pembelahan Umbi, Lama Perendaman, dan Konsentrasi Kolkhisin Pada Poliploidisasi Bawang Merah 'Sumenep'. Zuriat. 2: 17-26.

Poehlman, J. M and D. A. Sleper. 1995. Breeding Field Crops.Panama Publishing Corporation. New Delhi, India. PP. 278.

Rajagopal, C. and Kandhasamy. 2009. Genetic Variability of kazhappai Kizhangu (Gloriosa superba L.) in Tamil Nadu Assessed Using Morphological and Biochemical Traits. Journal of Agriculture. 47 (1-2) : 77 $79,2009$.

Rauf, J. T. Silva, A. A.Khan, A. Naveed. (2006). Consequences of plant breeding on genetic diversity. International Journal of Plant Breeding. 41, 1-21.

Royer, D. L. 2001. Stomatal Density and Stomatal Index as indicators of paleomosperic C02 Concentration. Review of Palaeobotany and Palynology 114 (2001) 1-28.

Suryo. 1995. Sitogenetika. Gadjah Mada University Press. Yogyakarta.

Thomas, H.1993. Chromosome Manipulation and Polyploidy. In Plant Breeding : Principal and prospects. M.D. Hayward, D. Basemark and I. Romagosa (Eds). Chapman and Hall. London. Page 79-92.

Zolock, S. A. 2003. Polyploidy in Daylily and Hosta. http://www.hostalibrary.org/misc/hybrid/pol yploidy.pdf. 